\title{
"An unnecessary cut?" multilevel health systems analysis of drivers of caesarean sections rates in Italy: a systematic review
}

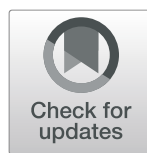

Valentina Laurita Longo ${ }^{1,2,3^{*}}$ (D), Emmanuel Nene Odjidja ${ }^{2+}$, Thierry Kamba Beia ${ }^{2,4+}$, Manuela Neri ${ }^{1}$, Karina Kielmann², Irene Gittardi ${ }^{5}$, Amanda Isabella Di Rosa ${ }^{2}$, Michela Boldrini', Gian Benedetto Melis ${ }^{1}$, Giovanni Scambia ${ }^{3,7 \dagger}$ and Antonio Lanzone $e^{3,7+}$

\begin{abstract}
Background: Improvements in medical technologies have seen over-medicalization of childbirth. Caesarean section (CS) is a lifesaving procedure proven effective in reducing maternal and perinatal mortality across the globe. However, as with any medical procedure, the CS intrinsically carries some risk to its beneficiaries. In recent years, CS rates have risen alarmingly in high-income countries. Many exceeding the World Health Organisation (WHO) recommendation of a 10 to $15 \%$ annual CS rate. While this situation poses an increased risk to women and their children, it also represents an excess human and financial burden on health systems. Therefore, from a health system perspective this study systematically summarizes existing evidence relevant to the factors driving the phenomenon of increasing CS rates using Italy as a case study.

Methods: Employing the WHO Health System Framework (WHOHSF), this systematic review used the PRISMA guidelines to report findings. PubMed, SCOPUS, MEDLINE, Cochrane Library and Google Scholar databases were searched up until April 1, 2020. Findings were organised through the six dimensions of the WHOHSF framework: service delivery, health workforce, health system information; medical products vaccine and technologies, financing; and leadership and governance.

Results: CS rates in Italy are affected by complex interactions among several stakeholder groups and contextual factors such as the hyper-medicalisation of delivery, differences in policy and practice across units and the national context, issues pertaining to the legal and social environment, and women's attitudes towards pregnancy and childbirth.

\footnotetext{
* Correspondence: valentina.lauritalongo@gmail.com

Emmanuel Nene Odjidja and Thierry Kamba Beia are share second authorship.

${ }^{\dagger}$ Giovanni Scambia and Antonio Lanzone are share senior authorship.

'Department of Surgical Sciences, Department of Obstetrics and

Gynaecology, University of Cagliari, SS 554 - bivio Sestu, Monserrato, 09032

Cagliari, Italy

${ }^{2}$ Queen Margaret University, Institute for Global Health and Development, Edinburgh EH21 6UU, Scotland, UK

Full list of author information is available at the end of the article
}

(C) The Author(s). 2020 Open Access This article is licensed under a Creative Commons Attribution 4.0 International License, which permits use, sharing, adaptation, distribution and reproduction in any medium or format, as long as you give appropriate credit to the original author(s) and the source, provide a link to the Creative Commons licence, and indicate if changes were made. The images or other third party material in this article are included in the article's Creative Commons. licence, unless indicated otherwise in a credit line to the material. If material is not included in the article's Creative Commons licence and your intended use is not permitted by statutory regulation or exceeds the permitted use, you will need to obtain permission directly from the copyright holder. To view a copy of this licence, visit http://creativecommons.org/licenses/by/4.0/ The Creative Commons Public Domain Dedication waiver (http://creativecommons.org/publicdomain/zero/1.0/) applies to the data made available in this article, unless otherwise stated in a credit line to the data. 
(Continued from previous page)

Conclusion: Mitigating the high rates of CS will require a synergistic multi-stakeholder intervention. Specifically, with processes able to attract the official endorsement of policy makers, encourage concensus between regional authorities and local governments and guide the systematic compliance of delivery units with its clinical guidelines.

Keywords: Caesarean section, Obstetrics, Childbirth overmedicalisation, Health Systems of West, Italy, Europe

\section{Abstracto}

Antecedentes: La cesárea (CS) es un procedimiento que salva vidas y que ha demostrado su eficacia en la reducción de la mortalidad materna y perinatal en todo el mundo. Sin embargo, como cualquier procedimiento médico, la cesárea intrínsecamente conlleva cierto riesgo para sus beneficiarias, especialmente para aquellas que clínicamente no la requieren. La OMS recomienda una tasa de 10-15\% de CS como estándar de buena práctica obstétrica. Sin embargo, en muchos países desarrollados el número de CS realizado por año continúa aumentando exponencialmente presionando los recursos limitados de los sistemas de salud. Si bien esta situación expone a las mujeres y a sus fetos a un mayor riesgo quirúrgico, también representa una excesiva carga financiera para los sistemas de salud.

Tema: Utilizando el Framework del Sistema de Salud de la OMS (WHOHSF) y utilizando a Italia como referencia, esta revisión tiene como objetivo resaltar las circunstancias que determinan la excesiva tasa de CS observada en muchos países desarrollados. Analizamos el problema a través de las seis dimensiones del WHOHSF: prestación de servicios, personal sanitario, información del sistema de salud; productos médicos, vacunas y tecnologías, financiación; y liderazgo y gobernanza. Las tasas de CS en Italia se ven afectadas por una compleja interacción entre varios grupos de interés y factores como la 'hiper-medicalización' de la prestación, las diferencias en las políticas y prácticas entre las unidades y en el contexto nacional, cuestiones relativas al entorno legal y social junto con las actitudes de las mujeres hacia el embarazo y el parto.

Conclusión: La reducción de las altas tasas de CS requerirá una intervención sinérgica que incluya a las partes interesadas en todos los niveles. Específicamente, intervenciones capaces de atraer el respaldo oficial de los responsables políticos, una alineación de puntos de vista entre las autoridades regionales y los gobiernos locales, y un cumplimiento sistemático de las directrices clínicas por parte de las unidades de prestación de servicios.

Palabras clave: Cesárea, Obstetricia, Sobremedicalización del parto, Sistemas de Salud Occidentales, Italia, Europa

\section{Abstrakt}

Hintergrund: Der Kaiserschnitt (CS) ist ein lebensrettendes Verfahren, das sich als wirksam erwiesen hat, um die mütterliche und perinatale Sterblichkeit weltweit zu reduzieren. Wie bei jedem medizinischen Verfahren birgt die CS jedoch ein gewisses Risiko für die Betroffenen, insbesondere für diejenigen, die sie medizinisch nicht benötigen. Die WHO empfiehlt eine Rate von 10-15\% CS als Standard für gute geburtshilfliche Praxis. In vielen entwickelten Ländern steigt die Zahl der jährlich durchgeführten CS jedoch weiterhin exponentiell an und setzt die begrenzten Ressourcen der Gesundheitssysteme unter Druck. Während diese Situation Frauen und ihre ungeborenen Babys einem erhöhten Operationsrisiko aussetzt, stellt sie auch eine übermäßige finanzielle Belastung für die Gesundheitssysteme dar.

Main body: Unter Anwendung des WHO Health System Framework (WHOHSF) und am Beispiel Italiens soll diese Übersicht die Umstände aufzeigen, die der in vielen Industrieländern beobachteten übermäßigen CS-Anzahl zugrunde liegen. Wir analysieren das Problem anhand der sechs Dimensionen des WHOHSF: Leistungserbringung, Gesundheitspersonal, Informationen über das Gesundheitssystem; medizinische Produkte, Impfstoffe und Technologien, Finanzierung sowie Führung und Kontrolle. In Italien werden die CS-Raten durch ein komplexes Zusammenspiel verschiedener Interessengruppen und Faktoren beeinflusst, wie z.B. die "Hyper-Medizinalisierung" der Entbindung, Abweichungen in Theroie und Praxis zwischen den Abteilungen und im nationalen Kontext, Fragen des rechtlichen und sozialen Umfelds sowie die Einstellung der Frauen zu Schwangerschaft und Geburt. 


\begin{abstract}
(Continued from previous page)
Fazit: Um die hohen Raten der CS zu verringern, ist ein synergetisches Vorgehen unter Einbeziehung der Beteiligten auf allen Ebenen erforderlich. Insbesondere sind Interventionen erforderlich, die die offizielle Zustimmung der politischen Entscheidungsträger finden, eine Abstimmung der Standpunkte zwischen regionalen und lokalen Behörden und eine systematische Einhaltung der klinischen Leitlinien durch die Geburtenstationen.
\end{abstract}

Schlüsselwörter: Kaiserschnitt, Geburtshilfe, Hyper-Medizierung bei der Geburt, Gesundheitssysteme des Westens, Italien, Europa

\section{Background}

Childbirth, as pregnancy, is a natural event. However, there is a growing international trend transforming delivery into a surgical procedure mainly via caesarean section (CS) [1]. CS can be a life-saving procedure in circumstances where the life of the mother and her newborn is at risk. However, for a non-complicated labour, conduct of a CS poses unnecessary risks and it places a strain of burden on the entire health system. Clinically, evidence suggests that CS is associated with short and long-term complications, which can affect not only the present delivery but also subsequent pregnancies. Furthermore, CS is associated with longer recovery time (in comparison to vaginal birth (VB) and severe complications which may increase the risk of severe perinatal morbidity and mortality. For the mother, the risk of death is between three to five times compared to VB and increases the risk of severe maternal morbidity by 10 and 15 times [2-5]. In response to the risks and costs which comes with CS, in 1985, the World Health Health Organisation defined the optimal rate of CS to be 10 to $15 \%$ of the total number of deliveries per year [6]. This rate was established using the best evidence available at that time and is still considered a standard obstetric target [4]. However, despite this recommendation and the risks attributable to CS, the annual global CS rate has continued to rise at an alarming pace particularly in high and middle-income countries $[1,7,8]$. With an annual average CS rate of $35 \%$, Italy is considered as one of the countries with the highest CS rates in Europe and the world at large. Comparative to Europe which has an average of $24.8 \%$, the CS rates in Italy has gained attention and raised concern [5]. From just $11 \%$ in 1980 to $38 \%$ in 2011, the pace of CS increase has also raised critical questions about its appropriateness with some scholars suggesting that these procedures are being performed without a clear medical indication $[5,9]$. In a recent report by the Italian Ministry of Health based on patient discharge records, the proportion of unnecessary CSs performed in 2010 was estimated to have reached approximately $43 \%$, classifying CS as a national public health threat [10]. As studies have continually shown that part of this situation arises from health system factors, this review aims to summarize and analyse these factors using the globally accepted WHO Building Blocks Health Systems Framework (WHOHSF).

\section{Methods}

\section{Conceptual framework}

The aim of this paper is to contribute to the contextual understanding of the increasing number of CSs being performned in in Italy from a health system perspective. Searching findings of published and unpublished literature, this study summarize the evidence in the context of Italian Health System using the WHOHSF [11]. This framework allows a systematic evaluation of the challenges faced by the HS with emphasis on every component of the system. It has been previously used in many settings especially in low and middle income countries [11-18].

Compared to other studies that have analyzed increasing CS rates from the clinical and health user perspectives [19-21], the WHOHSF was chosen to evaluate the drivers of HS challenges as a series of interacting dimensions, rather than as isolated factors [12, 22].

As demonstrated in this paper, the WHOHSF can be employed to assess not only the appropriateness of health services in general, but also particular practices such as CS delivery. Employing the WHOHSF framework therein offers a full comprehension of its subject based on the key multilevel components of the health system. Furthermore, although previous studies have analyzed the demand-related factors of CS rates in Italy, supply-related issues have remained understudied. For this reason, this systematic review analyzes the situation through all six components of the HS which includes service delivery, the health workforce, health system information, medical products vaccine and technologies, financing, and leadership and governance [11].

\section{Search strategy}

Using the WHOHSF as a guide, we conducted a review of the literature including technical reports, in regard to CS and the six building blocks of National Health Systems (NHS). The Preferred Reporting Items for Systematic Reviews and Meta-Analyses (PRISMA) [23] guided the review strategy. Publications included in this review have been produced by the WHO, the OECD, Italian 
Ministry of Health and Justice, Italian National Institute of Statistics and the Italian Penal Code. PubMed, SCOPUS, MEDLINE, Cochrane Library and Google Scholar databases were consulted, each search grouping keywords in English and Italian and using Medical Subject Headings $[\mathrm{MeSH}]$ related to CS use (i.e. "Caesarean Section", "Rates", "Incidence", "Prevalence", "Italy", "Europe", "Drivers", "Appropriateness", "Unnecessary", "Operative Delivery", "Surgical Delivery", "Health System", "Health Care", "Regional", "Disparities", "Classification", "Education", "Policy", "Practice", "Medical Liability", "Incentives"). Further articles were retrieved by screening the reference lists of identified literature. We included manuscripts in Italian and English only. The abstracts of all articles identified in each search were screened and selected for in-depth review when recognised for their relevance to the topic.

\section{Inclusion and exclusion criteria}

A retrospective search was conducted from January 1, 1987 to April 1, 2020. The inclusion criteria for review were:

1. Paper reports evidences pertaining to CS or childbirth on any of the components of the health system as defined by the WHOHSF framework. The primary findings of the study was based on Italy, however to buttress our points, we draw evidences from other similar settings (i.e. Europe and the United States (US).

2. Paper produced in either the English or Italian language.

The exclusion criteria for review includes:

1. Papers not meeting the criteria for inclusion.

\section{Methodological quality assessment and data extraction} The quality assessment of studies were undertaken using the 8-item Crowe Critical Appraisal Tool (CCAT) (Table 1) [75]. The sections of each document assessed included; the abstract, introduction (background and objective), study design, sampling methodology (when applicable), data collection, ethical considerations (when applicable), and results and interpretation (also classified as discussions). Each section was scored out of five with a possible total of 40 . From this, a percentage was calculated and classifying each paper into three levels of evidence quality. Low evidence was classified as literature with a score of $<33.3 \%$, medium quality with a score between $33.366 .6 \%$, and high quality with $>66.7 \%$. Each paper was assigned a unique identifier including descriptive information such as the study type. Data was independently extracted by VLL, MN and ENO, with each assessment result then compared. In circumstances of disagreement, discussions were held until consensus was reached.

\section{Synthesis of results}

Results were presented narratively under the components of a health system as provided by the WHOHSF conceptual framework. No meta-analysis was attempted for each section, as the included literature addressed different outcomes.

\section{Ethical approval}

No ethical approval was requested for this study as all evidence used in this review are publicly available.

\section{Results}

\section{Characteristics of studies}

Figure 1 is a schematic overview of all studies included in this review, with details relevant to each paper outlined in Table 1. One hundred fourteen full text articles were first reviewed and assessed for eligibility, 56 (49\%) excluded from the review. Reasons for exclusion included unrelated subject (32/56), academic correspondences (8/56), preprints without peer review (8/56) and articles in languages other than Italian and English (10/ 56). From the classifications conducted using the quality assessment tool, $41 \%$ of the studies were classified as high quality evidence, $9 \%$ as medium quality and $50 \%$ as low quality. Most of the included studies (71\%) were conducted after 2010 with the latest having been published in 2020.

\section{Service delivery}

In recent years, the development of technologies for the monitoring and assistance of deliveries has led to a 'hyper-medicalization' of pregnancy and labor [24]. Some of these practices, now a part of the modern obstetric routine, may contribute to the likelihood of CS use. For example, as most deliveries occur in hospital rather than at home, the routine use of technologies to monitor perinatal wellbeing during pregnancy and labor (e.g. electronic fetal monitoring [EFM]) may lead to falsepositive diagnoses of fetal distress. Additional contributors to CS also include the increased use of laborinducing drugs and the use of loco-regional anesthesia $[25,26]$. In the case of EFM, recent studies (including a meta-analysis of randomized trials) demonstrate that while continuous EFM in low-risk labor does not improve fetal outcomes, it does significantly increases the rate of CS and vaginal operative delivery [27-30]. Furthermore, while antenatal classes and educational programmes positively correlate to reduced chances to undergo a CS as the mode of delivery (Fig. 2), when compared to other European countries, attendance in 


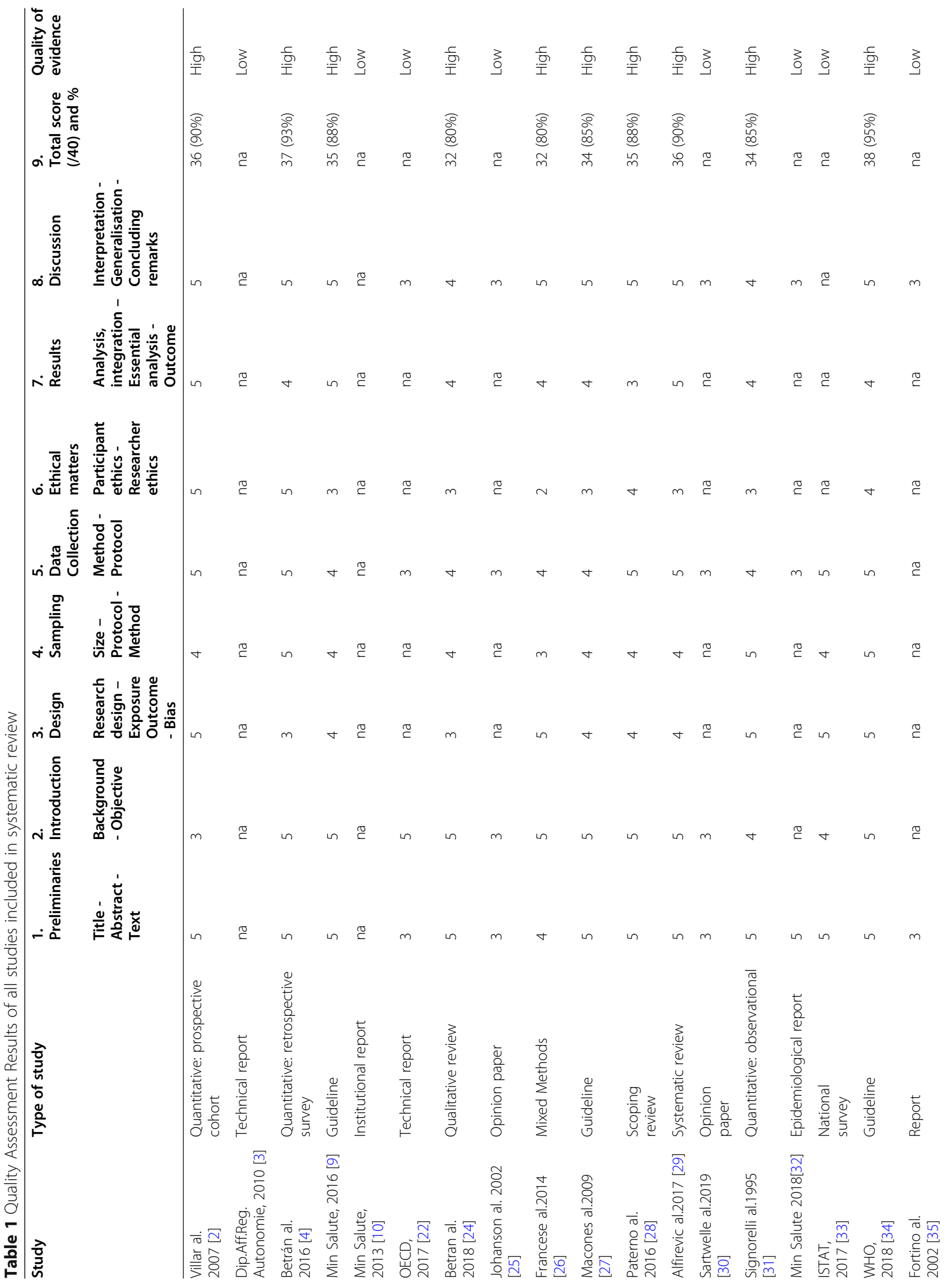




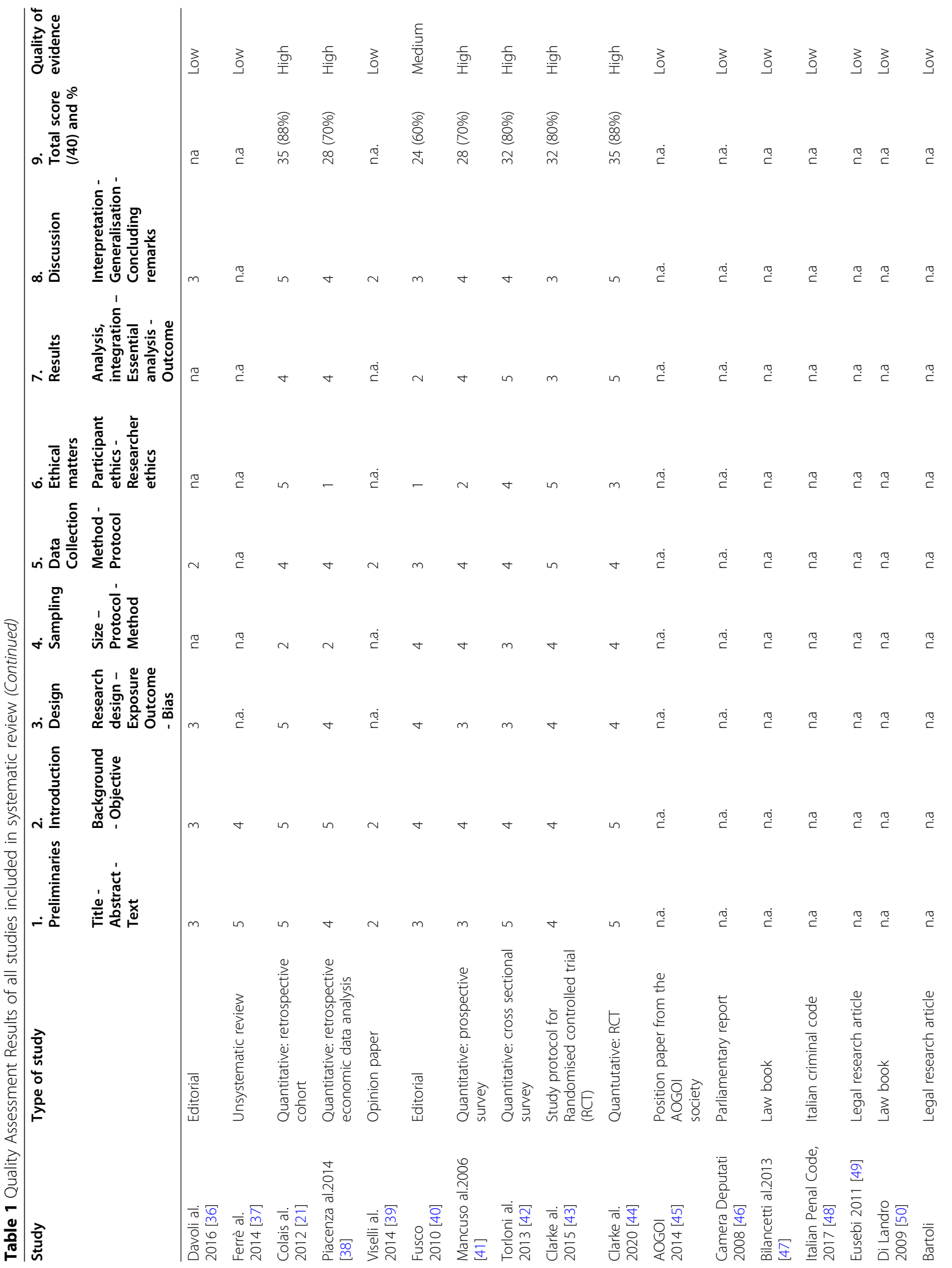




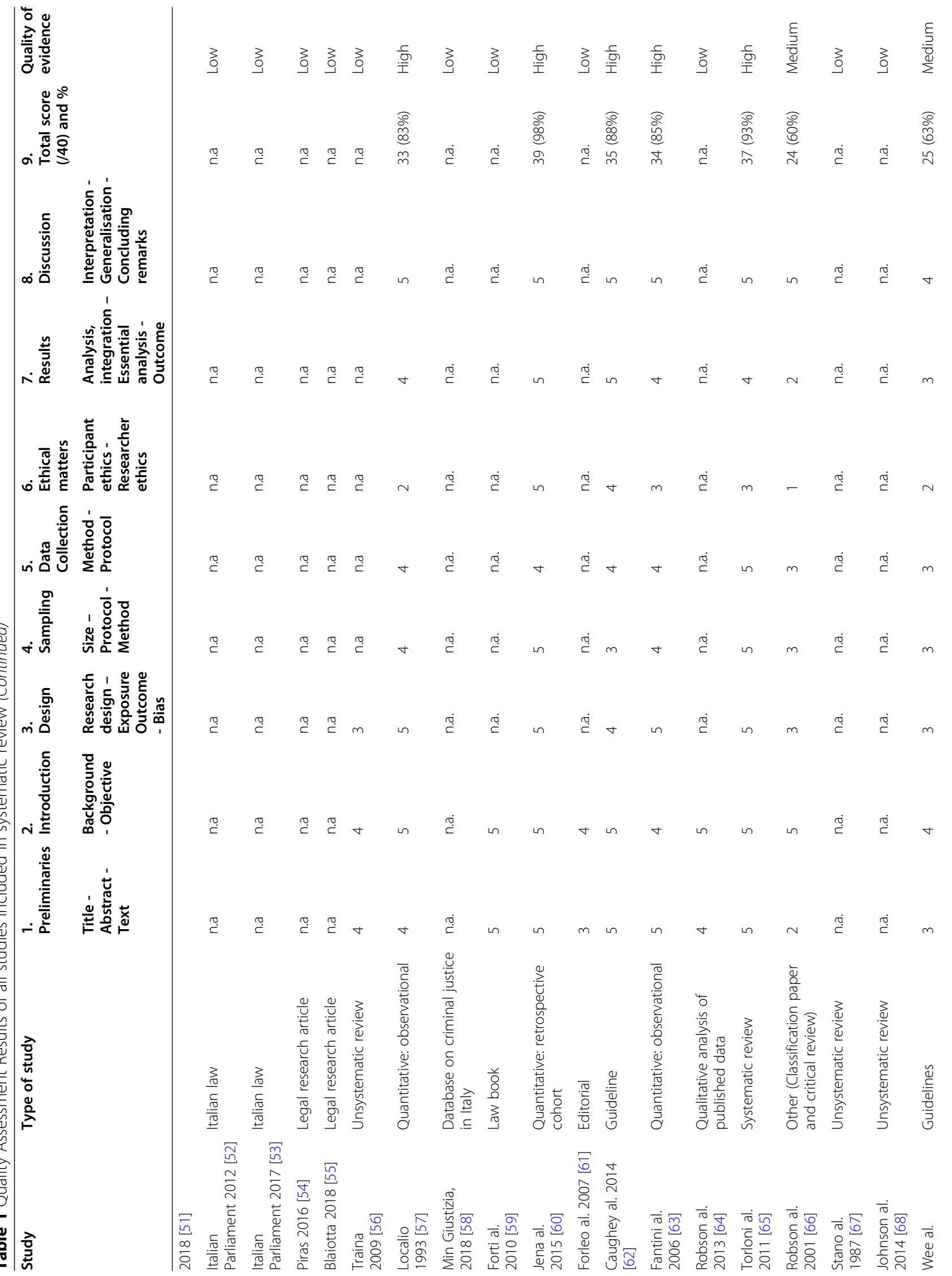




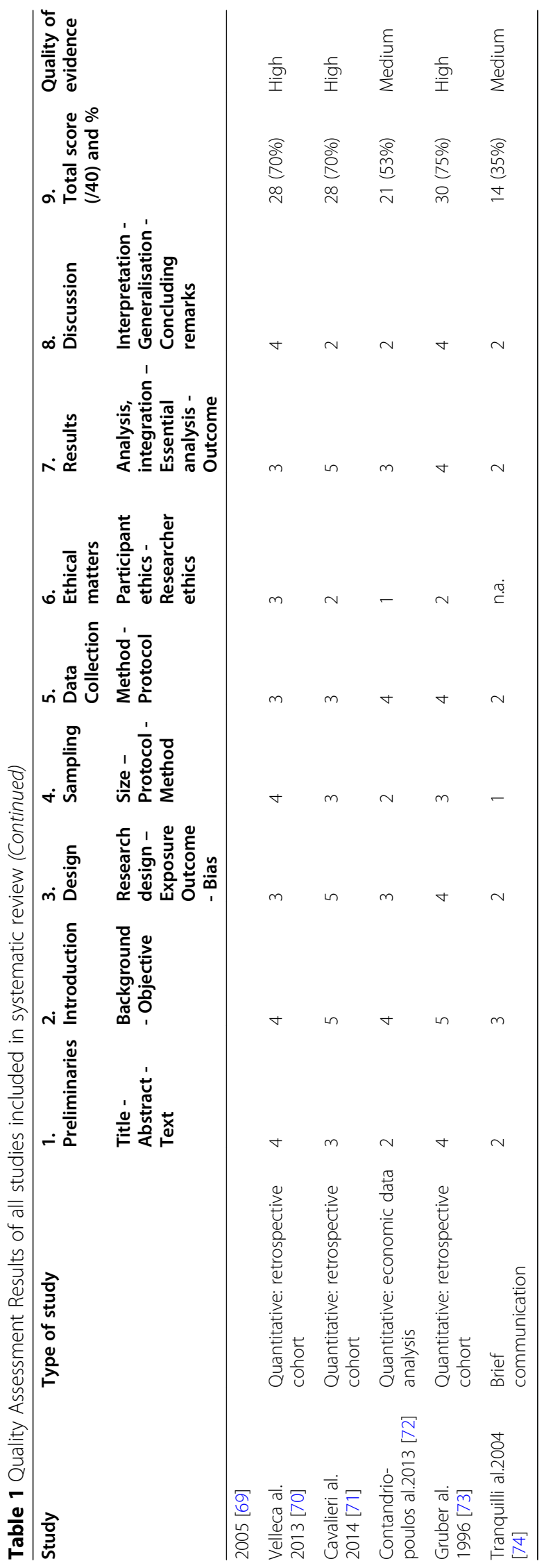




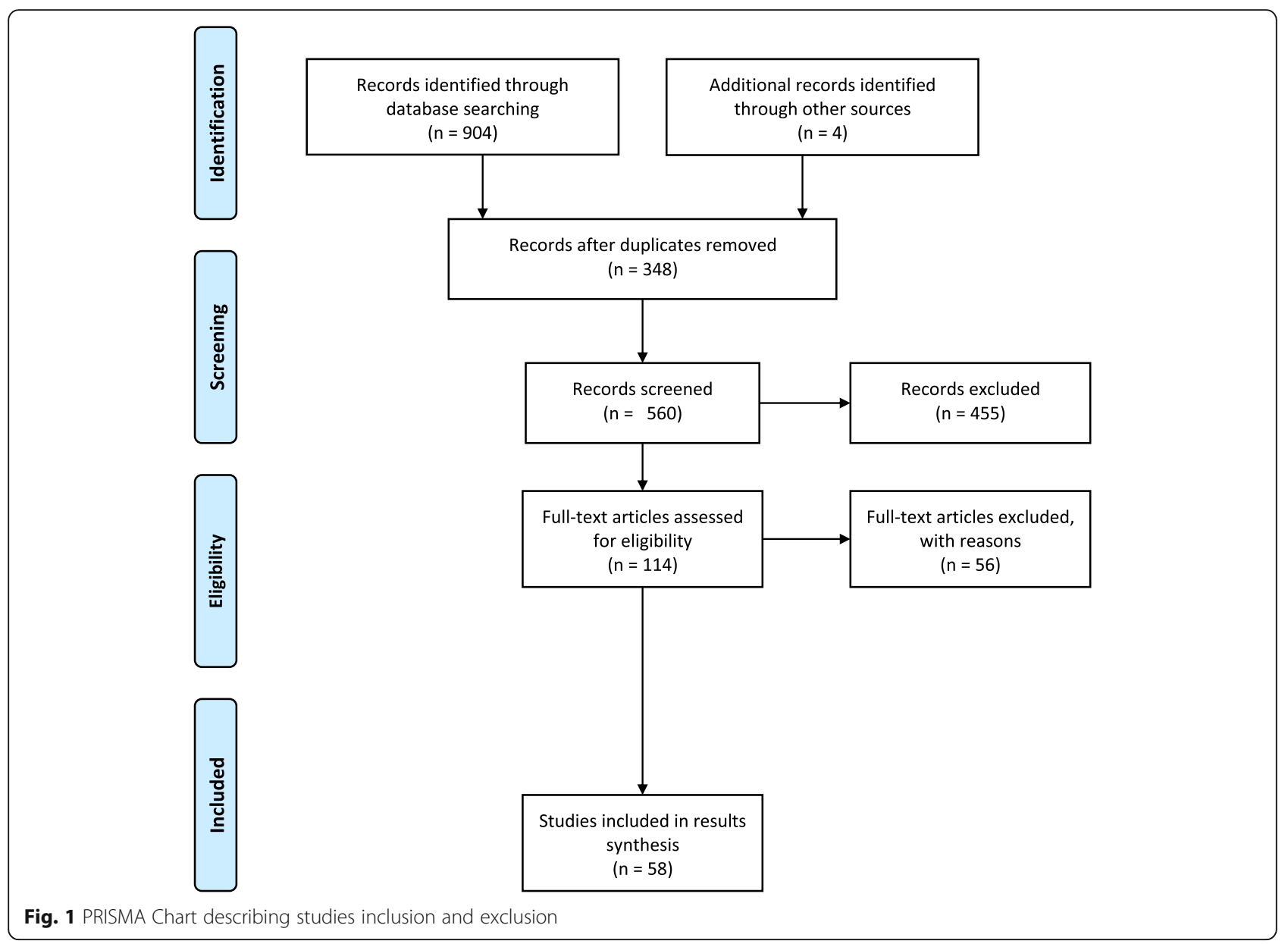

Italy is low [33, 34]. Yet the number of antenatal visits and ultrasound examinations performed often exceeds European standards [31, 32]. Although there is no doubt that some of these factors have contributed to making CS deliveries safer than in the past, they have also recast the natural physiological event of childbirth as a medical procedure in which health professionals are highly involved $[25,26]$.

Studies undertaken across Italy have reported significant geographic variability in the provision and quality of healthcare services, particularly between the northern and southern regions of the country [35, 36]. Closing this gap is one of the main challenges currently facing the national HS [37]. Factors indicative of this service gap include the lower CS rates observed in the North, where the quality and quantity of services provided are generally higher compared to the South. In southern regions, affected by greater financial deficits, CS rates are reported between 60 and $50 \%[3,9,21,38]$. A phenomenon only partially explained by the decentralization of the HS.

Significant differences in annual CS rates can also be observed when comparing public and private institutions, and across different delivery units. For example, the number of CS performed is higher in private/private-accredited hospitals compared to public hospitals $(53.6 \%$ vs. $32.6 \%)$ and in locations where the number of deliveries is low [32, 35]. Surprisingly, in hospitals with less than 500 deliveries (often decentralized in rural and semi-urban areas), the number of CSs performed largely exceeds those performed in hospitals with a higher level of activity and where there are more numerous complicated pregnancies and referrals [3, 9] (Figs. 3 and 4). Reasons for this trend might include the profitability of CS, convenience, time management issues, a lack of appropriate services, and staff shortages [3, 36]. The likelihood of performing a CS is also considered to be higher in deliveries that involve staff with less experience, limited assistance, or insufficient equipment; benefitting staff with the ability to schedule a CS delivery and reduce the risk of a complicated VD [39]. Simlarly, additional evidence finds that CSs are less frequent during weekends compared to working days, with the maximum number of CSs performed on Monday and the minimum on Saturday [40]. 


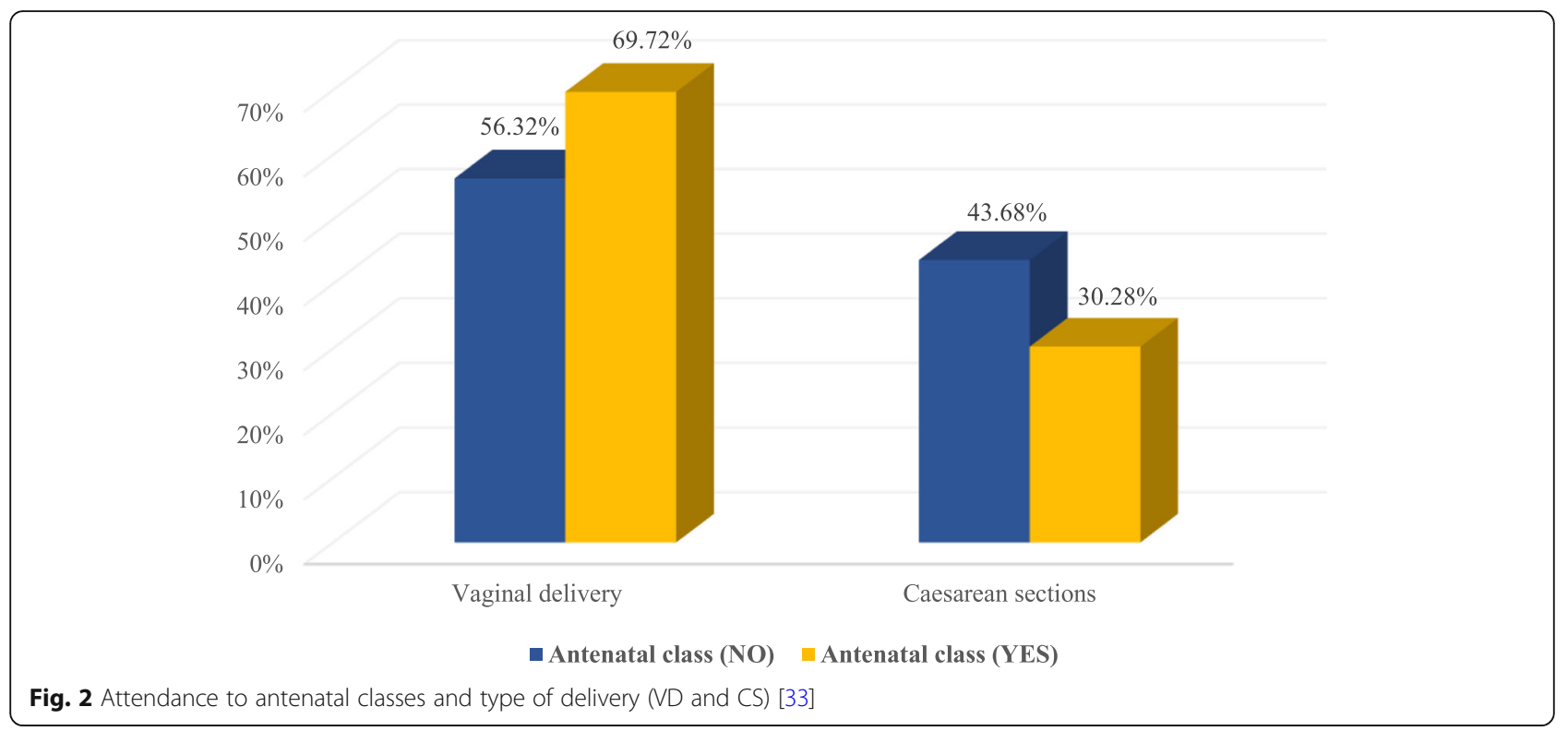

\section{Health workforce}

Another factor that may influence provider decisions to perform CS is their perceptions and behavior regarding professional risk [22, 26]. In Italy, healthcare professionals (HCPs) face an average of 15,000 medical liability actions per year. The highest number filed in Europe to date. Among them, obstetricians and gynecologists account for a high proportion of all malpractice suits (approximately $10 \%$ [45]). Although more than $90 \%$ of all malpractice suits result in acquittal, the personal and professional burden of this risk is noteworthy [46]. Unlike other European countries, medical malpractice in Italy can result in civil and criminal liability [47]. A doctor who is responsible for a patient's injury or death can face severe punishment, including up to 5 years imprisonment [37, 45, 46, 48, 49]. Additionally, in the Italian civil law system guilt is determined through the case-specific application of legal concepts. Their interpretation left to the discretion of the judiciary. In comparison, in the common law system (used in the United Kingdom, the US and Canada), trials are judged on the precedents of prior cases. Physicians tried under this system only liable for monetary compensation in the event of a conviction [50]. However, under the Italian civil system, doctors practice in conditions of legal uncertainty. The consequences of criminal negligence often unclear and inconsistent [51].

In 2012, Regulation 189/2012 (also known as the "Balduzzi" law) attempted to limit the responsibility of healthcare providers. The law states: "...health workers

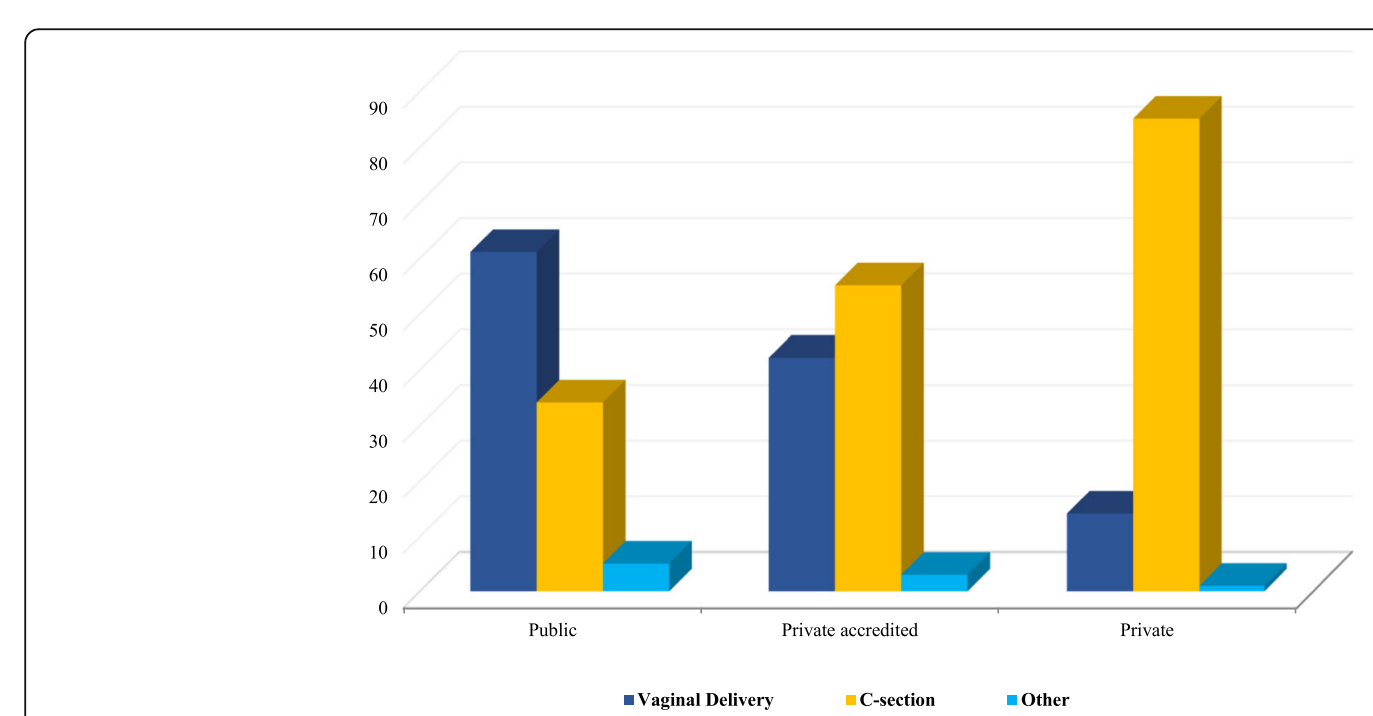

Fig. 3 Distribution of all deliveries by type of facility (public, private-accredited, private) [32] 


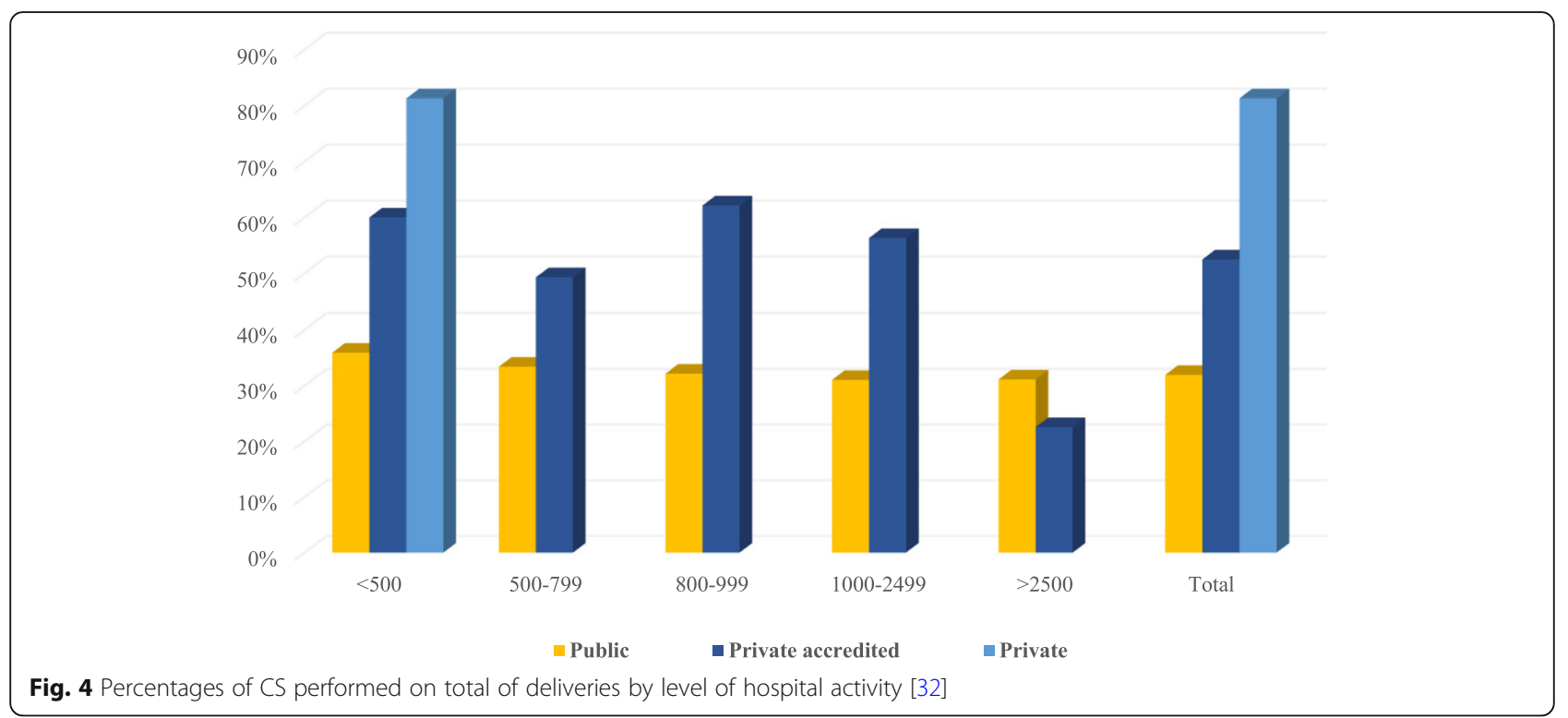

who in carrying out their activities adhere to guidelines and good practices accredited by the scientific community are not liable for criminal negligence." [52]. Here, criminal liability is linked in straightforward cases of negligence (culpa levis) to an HCPs' adherence to clinical guidelines and best practices. However, if considered gross negligence (culpa lata), the HCP will always be criminally responsible for any damages caused, regardless of their compliance with clinical guidelines [52]. In 2017, the "Gelli-Bianco" amendment aimed to further extend protections for professionals following clinical guidelines [53]. Under the amendment, adherence exempts the provider from criminal suits in cases of demonstrated incompetence/inexperience ("imperizia"). Whereas negligence ("negligenza") and imprudence ("imprudenza") remain a criminal offence [54]. Furthermore, this law extends medical liability from the physician alone to include all implicated HCPs (Italian Law No. 8 March 2017). However, despite these advancements, medical practices in Italy still face high levels of litigation, evidenced by inconsistencies in recent malpractice judegments passed by the Court of Cassation $[39,55]$.As a consequence of this legal uncertainty, physicians' behavior has progressively changed over time. Some suggest that the fear of legal action has contributed to the practice of 'defensive medicine' $[53,60]$. This includes protective clinical strategies such as the overuse of diagnostic testing and procedures to minimize legal claims $[22,56,57]$.

We argue that for obstetricians and gynecologists, the fear of litigation (particularly in the face of criminal liability) plays a significant role in the high CS rate in Italy [45]. In addition to an ambiguous legal system, another two factors influencing professional perceptions and behavior should be taken into account:

- The history of criminal investigation is highly stigmatizing for healthcare providers, leading the public to question a professional's reputation despite the outcome of a prosecution.

- The average duration of a criminal trial in Italy, as estimated by the Ministry of Justice in 2016, is approximately 4 years. This excludes preliminary investigations, which can last several years; and cases taken up by the Court of Cassation. This often results in physicians spending a considerable portion of their personal and professional lives under investigation $[51,58]$.

Additional data collected by the General Medical Council in Rome (Ordine Provinciale dei MediciChirurghi di Roma) and by researchers from the "Centro Studi Federico Stella" at the Catholic University of Milan further detail the magnitude of the problem [59]. Their findings include:

- $78.2 \%$ of physicians believe that they are at greater risk of criminal proceedings now than compared to the past

- $65.4 \%$ of Italian doctors report undue pressure on their daily clinical practice due to their vulnerability to legal action

- Incentives to practice defensive medicine include the previous judgments of the Court of Justice (57.9\%), the experiences of other colleagues (48.4\%), and fear of compromising their career $(27.8 \%)$ 
- $77.2 \%$ of the doctors interviewed believe the rules governing professional liability negatively affect the quality of care

Encouraged by legal climate in Italy, the practice of defensive medicine may have a significant influence on the quality of healthcare delivery and expenditure (e.g. in the prescription of unnecessary exams and procedures). Further evidenced in the experiences of obstetricians, Francese et al. [26] confirms a correlation between the fear of litigation and obstetricians' inclination to opt for CS. Particularly in ambiguous cases. In support of this fear, the US-based study by Jena et al. [60] shows a lower rate of malpractice lawsuits against physicians who performed more CSs.

Another workforce element found potentially influencing the high CS rate in Italy, concerns the level of skill required for the effective management of labour and delivery. Further supporting the practice of defensive medicine, obstetrics presents a challenging discipline that requires great experience at the risk of maternal and perinatal death. As part of postgraduate training, obstetricians must be able to predict labor risks, make an assessment and effectively intervene when necessary. Due to this pressure and with the increasing numbers of malpractice claims, countries like Italy and the US have seen more student gynacologists choosing to transfer from obstetrics to train in other "low risk" gynecological areas [61] so that the American College of Obstetricians and Gynecologists (ACOG) submitted a call for US-based gynaecologists not abandon the obstetrics discipline too soon [62]. Although there is a lack of similar evidence analyzing the training decisions of student gynaecologists in Italy, the Italian Association of Hospital Gynecologists and Obstetrics (AOGOI) regularly reports a dwindling interest in the uptake of obstetrics at the post-graduate level [61]. This "educational insecurity" could therefore influence the decisions of young doctors, especially in cases where the decision to perform a CS is percieved to be easier than managing an unpredictable VB.

\section{Information}

In Italy, the National Outcomes Programme (Piano Nazionale Esiti - PNE) includes CS rates as one of its indicators of quality of obstetric care at the inter-hospital and international level [21, 40, 63]. Lower CS rates per annum considered to indicate a higher quality of obstetric practice and better hospital performance, ultimately influencing a hospital's national ranking [63]. In particular, 'primary CS' (i.e. a CS performed for a woman for the first time) represents one of the most important quality indicators informing national healthcare development and intervention [36, 40]. As endorsed by the WHO, this monitoring of CS rates at facility-level is considered essential to guaranteeing that the procedure is being offered to the women who need it [4]. At present, there is no internationally approved classification for CSs [4]. Therefore, the absence of a standardized tool to classify CSs remains an obstacle to understanding trends in its delivery, preventing health facilities from comparing and monitoring CS rates. This being cited as one of the key barriers to the reduction of CS rates [4, 64].

To encourage the adoption of a common tool, in 2011 the WHO carried out a systematic review of the different methods being used to classify CSs around the world. As a result, the WHO agreed that the Robson 10-Group Classification System (RTGCS) was the most comprehensive and appropriate tool available [65]. Based on five clinical characteristics, the RTGCS groups all women into 10 classes, which are mutually exclusive and fully comprehensive [66]. This allows researchers to draw comparisons both at the facility and population levels. Data available from the RTGCs are potentially beneficial to the establishement of a behavioral protocol and contemporary standards for CS [32]. However, a number of hospitals and delivery units (especially small/private institutions) have not yet adopted the RTGCS.

\section{Medical products, vaccines and technologies}

The 'medicalization' of childbirth has created an environment in which medical products and technologies play an essential role in the delivery process now more than ever. In this paper we have discussed the impact of this medicalization on the likelihood of CS delivery. In addition to this phenomenon, the theory of induced-demand would suggest that after the supply of a good increases, more of that good is consumed $[67,68]$. As with all surgical procedures, CSs require a wider use of medical products and technologies compared to VDs, such as anesthesia, and other specialized products and equipment including the use of postpartum drugs (i.e. antibiotics, anticoagulants and pain-killers) [69]. For some of these drugs, their use is recommended for as long as a month after delivery. Furthermore, a study conducted by Villar et al. [2] on a cohort of approximately 100,000 women showed how those who underwent a CS were 5 times more likely to require antibiotic treatment compared to women who delivered spontaneously. Following this logic, it may be argued that the continuous availability of the tools of CSs may also play a role in decision-making relevant to delivery modes. This supply encouraging clinicians to perform CSs, particularly in ambiguous situations. 


\section{Financing}

The financing mechanism of the Italian HS constitutes a national health insurance program (i.e. universal health coverage intervention), providing individuals access to health care, free at the point of need. Constitutionally, all residents are entitled to receive a package of services, the "livelli essenziali di assistenza" (LEA) (essential levels of care). This includes most maternal health services, such as antenatal care, delivery, and postnatal care. The LEA determined and ensured by the national government. However, since the decentralization of the Italian HS, the LEA has been delivered both in publicly and privately accredited hospitals by the Regional Health Service (RHS) and local health authorities [37, 70]. Under this organisation, since 1995 reimbursement schemes have been based on DRGs (diagnosis-related groups). A system that classifies patients discharged by NHS hospitals in homogenous reimbursement groups [70]. Here, a CS is generally reimbursed at a higher value ( $€$ 2092/ 2782, per procedure with/without complications) than a VD ( $€ 1272 / 1619$ ' per procedure with/without complications) [10]. Reimbursements for deliveries are also becoming highly varied across different RHSs. Therefore, it is unsurprising that where RHS tariff systems provide a higher financial difference, providers demonstrate a higher rate of medically unjustifiable CSs. Cavalieri et al. [71] ascribes these findings to the theory of induced demand, suggesting that the inappropriate use of CS is a direct result of financial incentives. Thus, those RHSs receiving high reimbursement for CSs retaining the difference in funds $[26,32,71]$. Although the influence of this incentive varies across providers, it is evident that it is the case of private hospitals and facilities with a small number of deliveries. Such facilities, despite attending to lower numbers of high-risk pregnancies, conduct high CS rate [71].

Additionally, the income-target hypothesis conceptualises that money influences work practices in similar ways to the phenomenon described above. Individuals and institutions prone to adjustments in practice that would accomplish a high income [72]. Therefore, intersecting factors such as the increased reimbursement of CSs and decreasing fertility rates in Italy may also infleunce physicians' decisions concerning CS deliveries [73]. The recommendation of CS is cited in the literature as an example of standard care practices for the achievement of a 'target income'. This implies that physicians/institutions may use their position and authority over their patients, to generate income [73].

\section{Leadership/governance}

In Italy, all medical procedures including CSs are guided by the Ministry of Health $(\mathrm{MOH})$ national guidelines. The objective of these guidelines is to explicitly clarify the clinical circumstances in which a CS should be performed [9]. However, it has been observed (particularly in the South), that providers do not always adhere to $\mathrm{MOH}$ recommendations [21]. Thus, according to the guidelines many continue to perform 'inappropriate' CSs [3]. Reasons for this disregard may include financial gains or organizational constraints; these factors enhanced by the decentralization of the HS where each region has a certain degree of fiscal devolution. For example, in Campania (the Italian region with the highest CS rate, at approimatley 60\%) the number of CSs performed has risen in parallel with the introduction of the DRG reimbursement scheme [39]. This situation is also accentuated by the fact that some women perceive CS to be beneficial to them and their babies, and are allowed to request the procedure even in absence of clinical indicators supporting the principle of "auto-determination" [46, 74]. However, at present there is no specific law regulating elective CSs in Italy. The decision to offer this service left to the physician's discretion [9].This may also contributing to increasing CS rates, especially when women are not accurately informed of the potential risks of the procedure [32, 41].

\section{Discussions}

While it is clear from this review that health system factors drives the high CS rate, other demand factors and preference of women is also an influencing factor. Women have become increasingly more involved in the decision-making processes of their doctors throughout their pregnancies. Consequently, women's preferences for a mode of delivery may also influence service provision. According to Francese et al. [26], women's cultural perceptions of pregnancy and delivery have also changed. Today, women are less likely to accept the risk of adverse outcomes. Additionally, with more frequency, women perceive CSs as a safer and less painful procedure when compared to VDs [41]. At present, only one study has investigated preferred mode of delivery in Italian women. The main reported reasons for choosing a CS delivery among Italian women was the fear of pain assocated with VD and the opportunity to schedule the delivery. Furthermore, CS is perceived to be safer and less painful for the baby. Also, CS is associated with a reduced delay in returning to sexual activity and reduced odds of sexual impairment for the mother [42]. Women self reported that their choices was first influenced by a gynecologist then family and friends [42]. In such a context, it is important that women are properly informed about the potential risks and benefits of CS. A possible way to achieve this is through the provision of services that promote a positive pregnancy experience by including women in their obstetric care decisions from the time of conception to delivery. Examples of these 
services reported in the literature include ad hoc meetings, informative material and online services. Such interventions are usually designed to be women-centered and have demonstrated to positively influenced women's decision on the mode of delivery [43]. For example, an RCT conducted in Italy and other European countries in the period 2014-2015 to investigate women's attitude towards trial of labour after CS found that engaging women in decisions of delivery increased vaginal delivery by $11 \%$. This marginal improvement in vaginal delivery using this strategy, according to the authors, could avert $160,000 \mathrm{CS}$ and the health system $€ 150$ milion annually $[43,44]$. Furthermore, the high CS rate in Italy warrants a highly accurate monitoring of epidemiological data and hospital activity releant to CSs [21]. While the WHO has strongly advocated for the systematic use of the Robson classification, until now it has not been fully implemented in Italy [4]. This is particularly true in decentralized hospitals and private institutions, which were found to be major contributors to CS rates $[9,35]$. Among factors found to pontentially influence CS trend in Italy, this review has allowed to highlight the importance of the legal context in the practice of medicine in Italy, and area that is usually underinvestigated. However, while the influence of fear of litigation on medical decision-making is supported by the literature, more research is necessary to better understand the impact of defensive medicine on care outcomes.

\section{Conclusions}

In this study, we have considered the systemic complexities of increased CSs rates in Italy, emphasizing how different drivers, including non-medical factors, have contributed to current trends. In doing so, we recognize that our novel use of the WHOHSF as a diagnostic tool has made it possible to highlight how high CSs rates in Italy are not only an isolated clinical problem, but also one with roots in all six components of the HS. Consequently, it becomes clear that effective approaches to reduce unnecessary CSs would require coordinated efforts by all stakeholders. Particularly, with the official endorsement and support of policy makers, the alignment of regional authorities with local governments and pratictioners's increased adherence to clinical guidelines. Furthermore, we find the WHOHSF to be a critical tool for the future assessment of areas commonly neglected by medical journals. This offers the potential to facilitate the implementation of integrated evidence-based interventions, develop an cohesive health assistance model and improve the general quality of sexual and reproductive health services. Ultimately, this will contribute to the much needed optimization of CS use not only in Italy, but also in other high-income countries around the world.

\section{Abbreviations}

CeDAP: Certificato di assistenza al parto; CSs: Caesarean sections; DRG: Diagnosis-related groups; EFM: Electronic Fetal Monitoring; NHS: National Health System; HS: Health System; ISTAT: Istituto Nazionale di Statistica; LEA: Livelli Essenziali di Assistenza; MEDLINE: Medical Literature Analysis and Retrieval System Online; MINSAL: Ministero Della Salute; $\mathrm{MOH}$ : Ministry of Health; OECD: Organisation for Economic Co-operation and Development; PNE: Piano Nazionale Esiti; RCT: Randomized Controlled Trial; RHS: Regional Health Service; RTGCS: Robson 10-Group Classification System; TOLAC: Trial of Labour After Caesarean delivery; VB: Vaginal Birth; VBAC: Vaginal Birth After Caesarean delivery; VD: Vaginal Delivery; WHO: World Health Organisation; WHOHSF: World Health Organisation Building Blocks Health Systems Framework

\section{Acknowledgements}

Not applicable.

\section{Authors' contributions}

$V L L$ devised the paper, wrote the first draft of the article, and contributed overall leadership to the project. TKB, VLL, ENO, MN contributed to the literature reviews and to the selection of the more relevant articles. KK contributed to the development of the methodology and revisions of drafts. IG contributed to the writing of the paragraph "Health Workforce", to the search and review of the literature related to the legal context and to the analysis of legal contents. MB contributed to the review and analysis of economic items and participated in the writing of the paragraph "Financing" and "Medical Products, vaccines and technologies". AID contributed to postanalysis copy editing and content continuity in translation. ENO provided rounds of technical reviews and contributed to the writing of relevant sections. ENO and TKB took part to the writing and review of the manuscript. GMB, AL and GS contributed overall leadership to the project, and led revision of drafts. All authors contributed to the development of the framework, helped to the search and the analysis of the literature, and took part to the revision of the final edition of the paper. All authors read and approved the final version of this manuscript to the submission to BMC Pregnancy and Childbirth journal.

\section{Authors' information}

Authors of this paper have different backgrounds and expertices.VLL, TKB, $\mathrm{MN}, \mathrm{GBM}, \mathrm{AL}, \mathrm{GS}$ are medical doctors, with a clinical background and research interest in Obstetrics \& Gynecology. GS is also the former president of the SIGO (Italian society of Obstetrics and Gynecology). ENO is an epidemiologist and impact evaluator with key interests in health systems response to communicable and not-communicable diseases and maternal health. IG is a law graduate, specialised in medical laws and clinical malpractice claims; she currently practice as an attorney in Milan, Italy. KK is an antroplogist with a longstanding reputation in health systems and social sciences research. $\mathrm{MB}$ is a $\mathrm{PhD}$ candidate in Economics, currently doing research in health economics at the Univeristy of Bologna. AID is a PhD candidate in global public health, her expertise focuses on marginalised patient disease and treatment experiences.

\section{Funding}

Not applicable.

\section{Availability of data and materials}

This article relied on secondary data and published articles. All information/ data used are readily available for further analysis via the provided links in the reference section.

Ethics approval and consent to participate

Not applicable.

Consent for publication

Not applicable.

Competing interests

The authors declare that they have no competing interest. 


\section{Author details}

'Department of Surgical Sciences, Department of Obstetrics and Gynaecology, University of Cagliari, SS 554 - bivio Sestu, Monserrato, 09032 Cagliari, Italy. ${ }^{2}$ Queen Margaret University, Institute for Global Health and Development, Edinburgh EH21 6UU, Scotland, UK. ${ }^{3}$ Catholic University of Sacred Heart, 00168 Rome, Italy. ${ }^{4}$ Health Services Department, Copperbelt University, Kitwe, Zambia. ${ }^{5}$ Legal Department "Luca Santa Maria e associati", Via G. Serbelloni 1, 20122 Milan, Italy. ${ }^{6}$ Department of Economics, University of Bologna, Piazza Antonio Scaravilli 2, 40126 Bologna, Italy. ${ }^{7}$ Fondazione Policlinico Universitario Agostino Gemelli, IRCCS, Largo Agostino Gemelli 8, 00168 Rome, Italy.

Received: 10 February 2020 Accepted: 26 November 2020 Published online: 10 December 2020

\section{References}

1. Betrán AP, Ye J, Moller A, Zhang J, Gülmezoglu AM, Torloni MR. The increasing trend in caesarean section rates: global, regional and national estimates: 1990-2014. PLoS One. 2016;11:e0148343.

2. Villar J, Carroli G, Zavaleta N, et al. Maternal and neonatal individual risks and benefits associated with caesarean delivery: multicentre prospective study. Br Med J. 2007;335:1025-9.

3. Dipartimento per gli Affari Reginali e le Autonomie (DIPAFFRE) (IT). Conferenza Stato Regioni ed Unificata. Rep. Atti n. 137/CU del 16 Dicembre 2010. Rome, 2010

4. Betrán AP, Torloni MR, Zhang JJ, Gülmezoglu AM. WHO statement on caesarean section rates. BJOG. 2016;123:667-70.

5. Organisation for Economic Co-operation and Development (OECD). Caesarean sections (indicator). 2019. https://data.oecd.org/healthcare/ caesarean-sections.htm DOl: https://doi.org/10.1787/adc3c39f-en. Accessed 2019 July 28.

6. World Health Organization (WHO). Appropriate Technology for Birth. Lancet. 1985;326:436-7. https://doi.org/10.1016/S0140-6736(85)92750-3 http://www. sciencedirect.com/science/article/pii/S0140673685927503 DOl: doi: . Accessed 2019 July 28

7. Di Renzo GC, Malvasi A. Cesarean delivery: a comprehensive illustrated practical guide. Boca Raton: CRC Press; 2016

8. The Lancet Editorial. Stemming the global caesarean section epidemic. Lancet. 2018:392:1279.

9. Ministero della Salute, Sistema Nazionale per le Linee Guida dell'Istituto Superiore di Sanità (IT). Taglio Cesareo: una scelta appropriata e consapevole. Seconda parte. Rome: Ministry of Health (Ministero della Salute); 201.

10. Ministero della Salute (IT). Parti Cesarei, il 43\% ingiustificato. Rome: Ministry of Health (Ministero della Salute); 2013. http://www.salute.gov.it/portale/ news/p3_2_1_1_1.jsp?lingua=italiano\&menu=notizie\&p=dalministero\&id= 914. Accessed 2019 July 28

11. World Health Organization (WHO). Everybody's Business-- Strengthening Health Systems to Improve Health Outcomes: WHO's Framework for Action. Geneva: World Health Organisation; 2007. https://apps.who.int/iris/handle/1 0665/43918. Accessed 2019 July 28.

12. Mutale $W$, Bond $V$, Mwanamwenge MT, et al. Systems thinking in practice: the current status of the six WHO building blocks for health system strengthening in three BHOMA intervention districts of Zambia: a baseline qualitative study. BMC Health Serv Res. 2013;13:291.

13. Beran D. The impact of health systems on diabetes Care in low and Lower Middle Income Countries. Curr Diab Rep. 2015;15:1-13.

14. Binanay CA, Akwanalo CO, Aruasa W, et al. Building sustainable capacity for cardiovascular Care at a Public Hospital in Western Kenya. J Am Coll Cardiol. 2015:66:2550-60

15. Manyazewal T. Using the World Health Organization health system building blocks through survey of healthcare professionals to determine the performance of public healthcare facilities. Arch Public Health. 2017;75:50.

16. Saha M, Odjidja EN. Access to a skilled birth attendant in Bangladesh: what we know and what health system framework can teach us. Health Syst Policy Res. 2017:4:66.

17. Sherr K, Fernandes Q, Kanté AM, Bawah A, Condo J, Mutale W, et al. Measuring health systems strength and its impact: experiences from the African health initiative. BMC Health Serv Res. 2017:17.

18. Odjidja EN, Saha M, Kwanin C. Low uptake of intermittent preventive treatment in Ghana: an examination of health system bottlenecks. Strength Health Syst. 2018;2:75-8.
19. Stivanello E, Rucci P, Lenzi J, Fantini MP. Determinants of cesarean delivery: a classification tree analysis. BMC Pregnancy Childbirth. 2014;14(1):215.

20. Di Giovanni P, Garzarella T, Di Martino G, Schioppa FS, Romano F, Staniscia T. Trend in primary caesarean delivery: a five-year experience in ABRUZZO, ITALY. BMC Health Serv Res. 2018;18(1):514.

21. Colais P, Fantini MP, Fusco D, Carretta E, Stivanello E, Lenzi J, et al. Risk adjustment models for interhospital comparison of CS rates using Robson's ten group classification system and other socio-demographic and clinical variables. BMC Pregnancy Childbirth. 2012;12.

22. Organisation for Economic Co-operation and Development (OECD). Tackling Wasteful Spending on Health. Paris: OECD Publishing; 2017. https://doi.org/ 10.1787/9789264266414-en. Accessed 2019 July 28.

23. Moher D, Liberati A, Tetzlaff J, Altman DG, Altman D, Antes G, et al. Preferred reporting items for systematic reviews and meta-analyses: the PRISMA statement. PLoS Med. 2009:6(7):e100009.

24. Betrán AP, Temmerman M, Kingdon C, et al. Interventions to reduce unnecessary caesarean sections in healthy women and babies. Lancet. 2018 392:1358-68.

25. Johanson $R$, Newburn M, Macfarlane A. Has the medicalisation of childbirth gone too far? Br Med J. 2002;324:892-5.

26. Francese M, Piacenza M, Romanelli M, Turati G. Understanding inappropriateness in health spending: the role of regional policies and institutions in caesarean deliveries. Reg Sci Urban Econ. 2014;49:262-77.

27. Macones GA. Intrapartum fetal heart rate monitoring: nomenclature, interpretation, and general management principles. Obstet Gynecol. 2009; 114:192-202.

28. Paterno MT, McElroy K, Regan M. Electronic fetal monitoring and cesarean birth: a scoping review. Birth. 2016;43:277-84.

29. Alfirevic Z, Gyte G, Cuthbert A, Devane D. Continuous cardiotocography (CTG) as a form of electronic fetal monitoring (EFM) for fetal assessment during labour. Cochrane Database Syst Rev. 2017;2:CD006066.

30. Sartwelle TP, Johnston JC, Arda B, Zebenigus M. Cerebral palsy, cesarean sections, and electronic fetal monitoring: all the light we cannot see. Clin Ethics. 2019;14:107-14.

31. Signorelli C, Cattaruzza MS, Osborn JF. Risk factors for caesarean section in Italy: results of a multicentre study. Public Health. 1995:109:191-9.

32. Ministero della Salute (MINSAL) (IT). Certificato di assistenza al parto (CeDAP) Analisi dell'evento nascita - Anno 2015. Rome; 2018.

33. Istituto Nazionale di Statistica (ISTAT) (IT). Indagine campionaria sulle nascite e le madri. Metadati anno 2012. Rome; 2017.

34. World Health Organization (WHO). Recommendations non-clinical interventions to reduce unnecessary caesarean sections. Geneva: World Health Organisation; 2018. https://www.who.int/reproductivehealth/guidance-toreduce-unnecessary-caesarean-sections/en/. Accessed 2019 July 26.

35. Fortino A, Lispi L, D'Ippolito F, Ascone G. L'Eccessivo Ricorso al Taglio Cesareo: Analisi dei Dati Italiani. Rivista di Diritto delle Professioni Sanitarie. 2002. p. 287.

36. Davoli M, Colais P, Fusco D. Give birth in Italy is a "surgical" procedure Recenti Prog Med. 2016:107(11):559-61.

37. Ferrè $F$, de Belvis $A G$, Valerio $L$, et al. Italy: health system review. Health Syst Transit. 2014:16:1-168.

38. Piacenza M, Turati G. Does fiscal discipline towards subnational governments affect citizens' well-being? Evidence on health. Health Econ. 2014;23:199-224.

39. Viselli B. Ingenere: Troppi parti cesarei in Italia. II triplo del resto d'Europa. Rome: Fondazione Giacomo Brodolini; 2014. http://www.ingenere.it/articoli/ troppi-parti-cesarei-italia-il-triplo-del-resto-deuropa. Accessed 2019 July 28.

40. Fusco D, Davoli M, Lallo A, Perucci CA. Valutazione Nazionale degli Esiti del Parto: Taglio Cesareo. Agenans Monitor. 2010;26:51-9.

41. Mancuso A, De Vivo A, Fanara G, Settineri S, Triolo O, Giacobbe A. Women's preference on mode of delivery in southern Italy. Acta Obstet Gynecol Scand. 2006:85:694-9.

42. Torloni MR, Betrán AP, Montilla P, Scolaro E, Seuc A, Mazzoni A, et al. Do Italian women prefer cesarean section? Results from a survey on mode of delivery preferences. BMC Pregnancy Childbirth. 2013;13.

43. Clarke M, Savage G, Smith V, Daly D, Devane D, Gross MM, et al. Improving the organisation of maternal health service delivery and optimising childbirth by increasing vaginal birth after caesarean section through enhanced women-centred care (OptiBIRTH trial): Study protocol for a randomised controlled trial (ISRCTN10612254). Trials. 2015;16(1) 
44. Clarke M, Devane D, Gross MM, Morano S, Lundgren I, Sinclair M, et al. OptiBIRTH: A cluster randomised trial of a complex intervention to increase vaginal birth after caesarean section. BMC Pregnancy Childbirth 2020;20(1).

45. Associazione Ostetrici Ginecologi Ospedalieri Italiani (AOGOI) (IT). Convegno europeo Verso una direttiva europea a tutela di medici e pazienti. Rome: Edizioni Health Comunication; 2014. https://www.aogoi.it/media/1943/ rassegna-aogoi-2-luglio-2014.pdf. Accessed 2019 July 28.

46. Camera dei Deputati (IT). Commissione parlamentare di inchiesta sugli errori in campo sanitario e sulle cause dei disavanzi sanitari regionali. Relazione conclusiva. Gazzetta Ufficiale. Doc XXII-bis, no.10, XVI Legislatura. Rome: Italian Chamber of Deputies; 2008.

47. Bilancetti M, Bilancetti F. La responsabilità civile e penale del medico. 8th ed. Padova: Cedam; 2013.

48. The Italian Penal Code. Responsabilità colposa per morte o lesioni personali in ambito sanitario (IT) Art. 590 sexies, ref.to artt. 589 e 590. Rome: Gazzetta Ufficiale della Repubblica Italiana; 2017.

49. Eusebi L. Medicina difensiva e diritto penale "criminogeno". Riv Ital Med Leg. 2011;23:1085-06.

50. Di Landro AR. La colpa medica negli Stati Uniti e in Italia. II ruolo del diritto penale e il confronto col sistema civile. Giappichelli: Torino; 2009.

51. Bartoli R. Riforma Gelli Bianco e Sezioni Unite non placano il tormento: una proposta per limitare la colpa medica. Diritto Penale Contemporaneo. 2018; 5:233-48.

52. Italian Parliament, Italian Law 8 November 2012 n. 189, “Disposizioni urgenti per promuovere lo sviluppo del Paese mediante un più alto livello di tutela della salute", c.d. "Decreto Balduzzi", in Gazzetta Ufficiale della Repubblica Italiana 10 novembre 2012

53. Italian Parliament, Italian Law 8 March 2017 n. 24, "Disposizioni in materia di sicurezza delle cure e della persona assistita, nonché in materia di responsabilità professionale degli esercenti le professioni sanitarie". c.d. "Legge Gelli-Bianco", in Gazzetta Ufficiale della Repubblica Italiana 17 marzo 2017.

54. Piras P. X Forum permanente sulla responsabilità professionale sanitaria. La riforma della colpa medica nell'approvanda legge Gelli-Bianco. Arezzo: Ospedale San Donato; 2016. [viewed 22 July 2018]. Available from: https:// www.penalecontemporaneo.it/d/4585-la-riforma-della-colpa-medica-nellapprovanda-legge-gelli.

55. Blaiotta R. Niente resurrezioni, per favore. A proposito di S.U. Mariotti in tema di responsabilità medica. Diritto Penale Contemporaneo. 2018;6:1-10.

56. Traina F. Medical malpractice: the experience in Italy. Clin Orthop. 2009:467: 434-42.

57. Localio AR, Lawthers AG, Bengtson JM, et al. Relationship between malpractice claims and cesarean delivery. JAMA. 1993;269:366-73.

58. Ministero della Giustizia (IT). Monitoraggio della giustizia penale - anno 2018. Rome. p. 2018. https://www.giustizia.it/giustizia/it/mg_1_14_1. page?facetNode_1=4_26\&contentld=SST1288006\&previsiousPage $=$ mg_1_14. Accessed 23 July 2018.

59. Forti G, Catino M, D’Alessandro F, Mazzucato C, Varraso G. Il problema della medicina difensiva. Una proposta di riforma in materia di responsabilità penale nell'ambito dell'attività sanitaria e gestione del contenzioso legato al rischio clinico. Centro Studi Federico Stella sulla Giustizia Penale e la Politica Criminale. Pisa: Edizioni ETS; 2010

60. Jena AB, Schoemaker L, Bhattacharya J, Seabury SA. Physician spending and subsequent risk of malpractice claims: observational study. BMJ. 2015;351: h5516.

61. Forleo RC, Cavalieri AF, Forleo P. 2007 Come educare all'assistenza alla nascita. Gyneco AOGOI. 2007;7:17-18.

62. Caughey AB, Cahill AG. Guise J-, rouse DJ. Safe prevention of the primary cesarean delivery this document was developed jointly by the with the assistance of. Obstet Gynecol. 2014;210(3):179-93.

63. Fantini MP, Stivanello E, Frammartino B, et al. Risk adjustment for interhospital comparison of primary cesarean section rates: need, validity and parsimony. BMC Health Serv Res. 2006;6:100.

64. Robson M, Hartigan L, Murphy M. Methods of achieving and maintaining an appropriate caesarean section rate. Best Pract Res Clin Obstet Gynaecol. 2013;27:297-308

65. Torloni MR, Betran AP, Souza JP, Widmer M, Allen T, Gulmezoglu M, et al. Classifications for cesarean section: A systematic review. PLoS One 2011;6(1).

66. Robson M. Classification of caesarean sections. Fetal Matern Med Rev. 2001; $12: 23-39$
67. Stano M. A clarification of theories and evidence on supplier-induced demand for Physicians' Services. J Hum Resour. 1987:22:611-20.

68. Brown ECF. Health reform and theories of cost control. J Law Med Ethics. 2018:46(4):846-56

69. Wee MY, Brown H, Reynolds F. The National Institute of clinical excellence (NICE) guidelines for caesarean sections: implications for the anaesthetist. Int J Obstet Anesth. 2005;14:147-58.

70. Velleca M, Petrarca G, Perrone F. DRG system in Italy: evaluation of different reimbursements for surgical procedures at national, Regional and Hospital Level Value in Health, vol. 16; 2013. p. A245.

71. Cavalieri M, Guccio C, Lisi D, Pignataro G. Financial incentives and inappropriateness in health care: evidence from Italian cesarean sections. Finanz Archiv. 2014;70:430-57.

72. Contandriopoulos D, Perroux M. Fee increases and target income hypothesis: data from Quebec on physicians' compensation and service volumes. Healthc Policy. 2013;9:30-5.

73. Gruber J, Owings M. Physician financial incentives and cesarean section delivery. RAND J Econ. 1996;27:99-123.

74. Tranquilli AL, Giannubilo SR. Cesarean delivery on maternal request in Italy. Int J Gynaecol Obstet. 2004;84(2):169-70.

75. Crowe M. Crowe critical appraisal tool (CCAT) user guide. Scotland: Conchra House; 2013.

\section{Publisher's Note}

Springer Nature remains neutral with regard to jurisdictional claims in published maps and institutional affiliations.
Ready to submit your research? Choose BMC and benefit from:

- fast, convenient online submission

- thorough peer review by experienced researchers in your field

- rapid publication on acceptance

- support for research data, including large and complex data types

- gold Open Access which fosters wider collaboration and increased citations

- maximum visibility for your research: over $100 \mathrm{M}$ website views per year

At $\mathrm{BMC}$, research is always in progress.

Learn more biomedcentral.com/submissions 